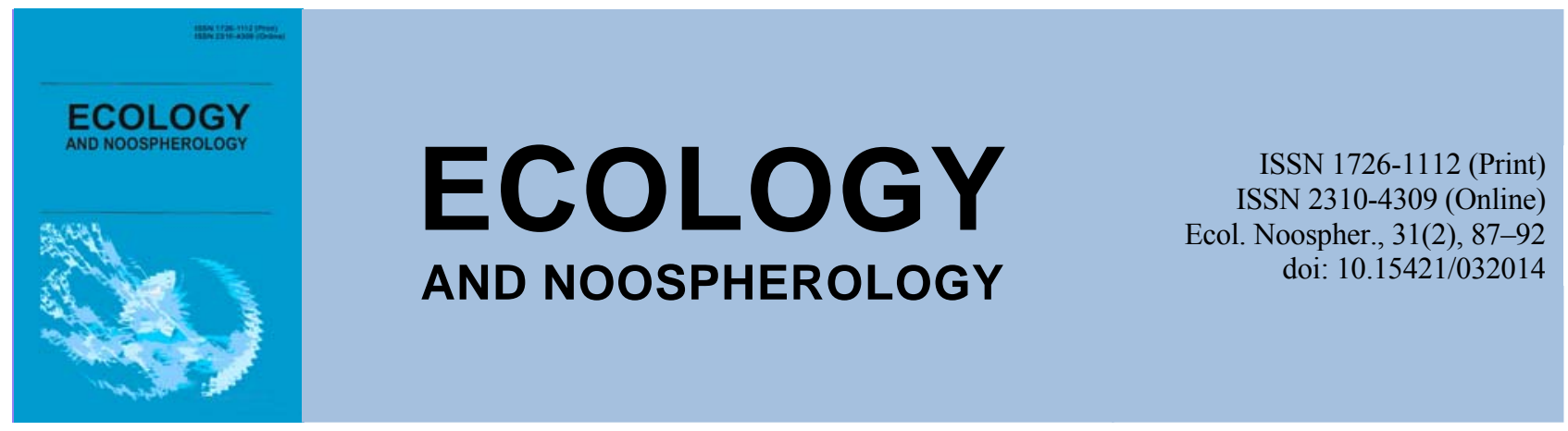

\title{
Influence of phytoncide activity of Thuja occidentalis L. on strains of microorganisms under the action of car load (Dnipro city)
}

\author{
T. V. Sklyar, T. I. Yusypiva, O. O. Slobodyanyuk \\ Oles Honchar Dnipro National University, Dnipro, Ukraine
}

Article info

Received 14.11.2020

Received in revised form

18.11.2020

Accepted 23.11.2020

Oles Honchar Dnipro

National University,

Gagarin Ave., 72, Dnipro,

49010, Ukraine.

Tel.: +38096-836-03-37

E-mail: JusypivaTatjana@i.ua
Sklyar, T. V., Yusypiva, T. I., Slobodyanyuk O. O. (2020). Influence of phytoncide activity of Thuja occidentalis $L$. on strains of microorganisms under the action of car load (Dnipro city). Ecology and Noospherology, 31(2), 87-92. doi:10.15421/032014

Landscaping of modern cities is impossible without increasing the area of green planting, which performs the function of turning the environment into more health-friendly one. Especially valuable are the species of ornamental plants that have high volatile activity. Because volatiles regulate the balance of pathogenic microflora in the air of cities, they significantly improve people's living conditions. According to the results of a previous study it was found that Thuja occidentalis L. and Th. plicata Donn ex D. Don $f$. "Zebrina" had the highest bactericidal activity during the winter among members of the family Cupressaceae. Given the frost, wind, gas and smoke resistance of Th. occidentalis, the aim of the study was to investigate the dynamics of phytoncide activity of the needles of this tree species during the year in a relatively clean zone and under the influence of vehicle emissions on plants in the urban ecosystem of Dnipro. The material was collected in all seasons of the year at two monitoring points in Dnipro, which differ in the level of environmental pollution by vehicle emissions. Traffic intensity was determined by the Potichuk \& Pilipaka method. Antimicrobial action of Th. occidentalis was studied by the method of placing the crops of microbial test cultures under the effect of volatile secretions of needles and evaluating the result on a scale of phytoncide activity. The test subjects were Staphylococcus epidermidis, Staphylococcus aureus, Micrococcus sp., Bacillus subtilis, Esherechia coli, Pseudomonas fluorescens, Candida albicans. Studies have shown that in a relatively clean area and under the action of traffic loads, the inhibitory effect of needles on the studied strains of microorganisms changes during the year: in winter it is the smallest, in spring begins to grow, in summer is maximum, and in autumn decreases again. Under the man-made growth conditions, the greatest volatile activity of Th. occidentalis performs on test objects such as: S. aureus, Micrococcus sp. and E. coli. When affected by car load, there is significant inhibition of phytoncide production by needles in the presence of $C$. albicans, to a lesser extent - Ps. fluorescens and B. subtilis. It is recommended to use Th. occidentalis in landscaping of urban areas with moderate traffic.

Keywords: Thuja occidentalis L.; phytoncide activity; needles; vehicle emissions

\section{Вплив фітонцидної активності Thuja occidentalis L. на штами мікроорганізмів за дії автотранспортного навантаження (м. Дніпро)}

\author{
Т. В. Скляр, Т. І. Юсипіва, О. О. Слободянюк
}

Дніпровський національний університет імені Олеся Гончара, Дніпро, Украӥна

Проаналізовано вплив викидів автотранспорту на фітонцидну активність хвої Thuja occidentalis L. в урбоекосистемі м. Дніпра. Показано, що як в умовах Ботанічного саду Дніпровського національного університету імені Олеся Гончара (умовний контроль), так і за дії автотранспортного навантаження пригнічувальна дія хвої на досліджені штами мікроорганізмів змінюється протягом року, підвищуючись влітку і зменшуючись взимку. Установлено, що в техногенних умовах зростання найбільшу фітонцидну активність Th. occidentalis справляє на такі тест-об'єкти, як Staphylococcus aureus, Micrococcus sp. та Esherechia coli. Виявлено, що у рослин, які зростають за хронічної дії автотранспортного забруднення, фітонцидна активність хвої істотно знижувалася в культурах Candida albicans, меншою мірою - у Pseudomonas fluorescens 
та Bacillus subtilis. Рекомендовано використовувати Th. occidentalis в озелененні міських територій 3 помірним автотранспортним навантаженням.

Ключові слова: Thuja occidentalis L.; фітонцидна активність; хвоя; викиди автотранспорту

\section{Вступ}

Благоустрій сучасних міст неможливий без збільшення площі зелених насаджень, що мають високі естетичні та санітарно-гігієнічні властивості (Bessonova \& Ponomaryova, 2017; Iusypiva \& Miasoid, 2016). Особливо цінні в даному аспекті породи хвойних деревних i чагарникових декоративних рослин, які виділяють велику кількість біологічно активних речовин (Yusypiva, Slobodyanyuk, 2019). Фітонциди - це комплекс різноманітних летких i нелетких хімічних сполук, що виробляються рослинами, мають бактерицидні, фунгіцидні та протистоцидні властивості й виконують імунну функцію в рослинному організмі (Tokin, 1980). Оскільки фітонциди впливають на склад мікрофлори повітря й пригнічують ріст багатьох видів мікроорганізмів, вони відіграють значну роль у взаємовідносинах видів у біоценозах.

Ці якості фітонцидів незамінні в міських екосистемах, де на організм людини діє багато несприятливих i небезпечних екологічних чинників, пов'язаних із наявністю різних видів забруднення довкілля. Оскільки фітонциди регулюють баланс патогенної мікрофлори в атмосферному повітрі міст (Volodarets, Gluchov, Zaitseva, 2018; Yusypiva, 2019), вони суттєво покращують умови життя людей.

Представники родини Cupressaceae F. Neger зарекомендували себе як цінні високодекоративні інтродуценти, що мають лікувальні й фітонцидні властивості (Tsytsyura, Holovatuk, 2016; www.ieenas.org).

У попередніх дослідженнях (Yusypiva, Slobodyanyuk, 2019) було вивчено фітонцидну активність декоративних видів родини Cupressaceae протягом зимового періоду в умовах Ботанічного саду Дніпровського національного університету імені Олеся Гончара (м. Дніпро). За результатами експериментальної роботи виявлено, що за зменшенням бактерицидної активності досліджені представники родини Cupressaceae були розташовані таким чином: Thuja occidentalis L. = Th. plicata Donn ex D. Don f. "Zebrina" > Juniperus. x media V.D. Dmitriev f. "Blue Gold" > J. squmata Buch.-Ham. ex D. Don f. "Meyeri" > Chamaecyparis obtusa (Siebold \& Zucc.) Endl. $>$ C. lawsoniana Spach. Оскільки найвище значення дослідженого показника виявилося у туї західної та враховуючи, що ця порода $\epsilon$ морозо- й вітростійкою, що важливо в умовах степової зони України, а також добре переносить вплив газодимового забруднення й кіптяви (www.ieenas.org), характерних для сучасних урбоекосистем, нами було поставлено завдання вивчити динаміку фітонцидної активності цього виду протягом усього року.

Зважаючи на все вищевикладене, мета роботи дослідити фітонцидну активність Thuja occidentalis L. на штами мікроорганізмів в умовно чистій зоні та оцінити іiі зміни за дії на рослини викидів автотранспорту в умовах урбоекосистеми м. Дніпра.

\section{Матеріали та методи досліджень}

Матеріал збирали в усі сезони року (19.10.2019 р., 11.12.2019 p., 30.03 .2020 p., $\quad 07.07 .2020$ p.) у двох моніторингових точках м. Дніпра, що відрізняються рівнем забруднення довкілля викидами автотранспорту. Інтенсивність руху автотранспорту визначали за методикою Potichuk \& Pilipaka (2013).

Моніторингова точка 1 - Ботанічний сад Дніпровського національного університету імені Олеся Гончара (ДНУ), де концентрації забруднювачів не перевищують ГДК (Pasichnyy \& Serdyuk, 2002; Ecological passport .., 2016).

Моніторингова точка 2 розташована на Січеславській Набережній, яка протягом доби має велике транспортне навантаження (середня інтенсивність руху автотранспорту за нашими підрахунками 1085 шт./год.). За даними Dolzhenkova \& Petrova (2007), за умови, коли по вулиці за годину проїхало 112-150 автомобілів, інтенсивність руху вважають низькою, 334-710 - середньою, 750-1125 високою. Тому моніторингова точка 2 належить до найбільш забруднених вулиць м. Дніпра. Інтенсивність руху на ній перевищує показники максимальної завантаженості міст автотранспортом (Dolzhenkova \& Petrova, 2007)

Об'єктом дослідження була туя західна Thuja occidentalis L. із родини Кипарисові (Cupressaceae F. Neger), яка має високі декоративні та естетичні якості (Zaitseva \& Opanasenko, 2008). Проби пагонів (по 3 штуки 3 кожної модельної рослини) відбирали з південно-східного боку крони 33 модельних рослин у кожній моніторинговій точці.

Дослідження фітонцидної активності здійснювали 3 використанням методики «опарення» посівів мікробних тест-культур леткими виділеннями хвої. Тест-об'єктами слугували такі штами мікроорганізмів 3 колекції культур кафедри мікробіології, вірусології та біотехнології ДНУ: Staphylococcus epidermidis, Staphylococcus aureus, Micrococcus sp., Bacillus subtilis, Esherechia coli, Pseudomonas fluorescens, Candida albicans.

Для посіву мікробних культур застосовували живильний агар для культивування мікроорганізмів (ГРМАГАР). У чашку Петрі на поверхню живильного середовища висівали добову культуру мікроорганізмів мікробіологічною петлею діаметром 2 мм (посів штрихом), на поверхні нижньої чашки-«кришки» рівномірно розподіляли екстракти туї таким чином, щоб виключити контакт з живильним середовищем.

Опарення мікроорганізмів леткими виділеннями хвойних здійснювали протягом 4 год з 12-ї до 16-ї години за кімнатної температури, після чого чашки Петрі поміщали на 20 год до термостату за температури $37{ }^{\circ} \mathrm{C}$ (Tsybulya, 2001; Bakulin et al., 2010). Контрольні чашки 3 посівами мікробіологічних культур не обробляли виділеннями рослин. Оцінку антимікробної дії летких виділень туї західної проводили у порівнянні 3 контрольними посівами за шкалою фітонцидної активності:

0 - відсутність дії, спостерігається суцільний ріст мікробної культури;

1 бал - слабка дія, пригнічення росту культури в середній частині посівів (не більше 20-30\% довжини штриха);

2 бали - помірна дія (пригнічення росту культури до $40-50 \%$ довжини штриха);

3 бали - сильна дія, відзначено незначний ріст культури тільки на кінцях штриха;

4 бали - дуже сильна дія, повна відсутність росту мікробної культури (Tsybulya, 2001; Bakulin et al., 2010).

Для аналізу фітонцидної активності розраховували середнє арифметичне (M), похибку середнього арифметичного $(\mathrm{m})$, для порівняння вибірок використовували $\mathrm{t}$-критерій Стьюдента при $\mathrm{p}<0,05$.

\section{Результати та їх обговорення}

Наші дослідження свідчать про зміни протягом року фітонцидної активності хвої Th. occidentalis як в умовно чистій зоні, так і в техногенних умовах м. Дніпра (рис. 1-4). 


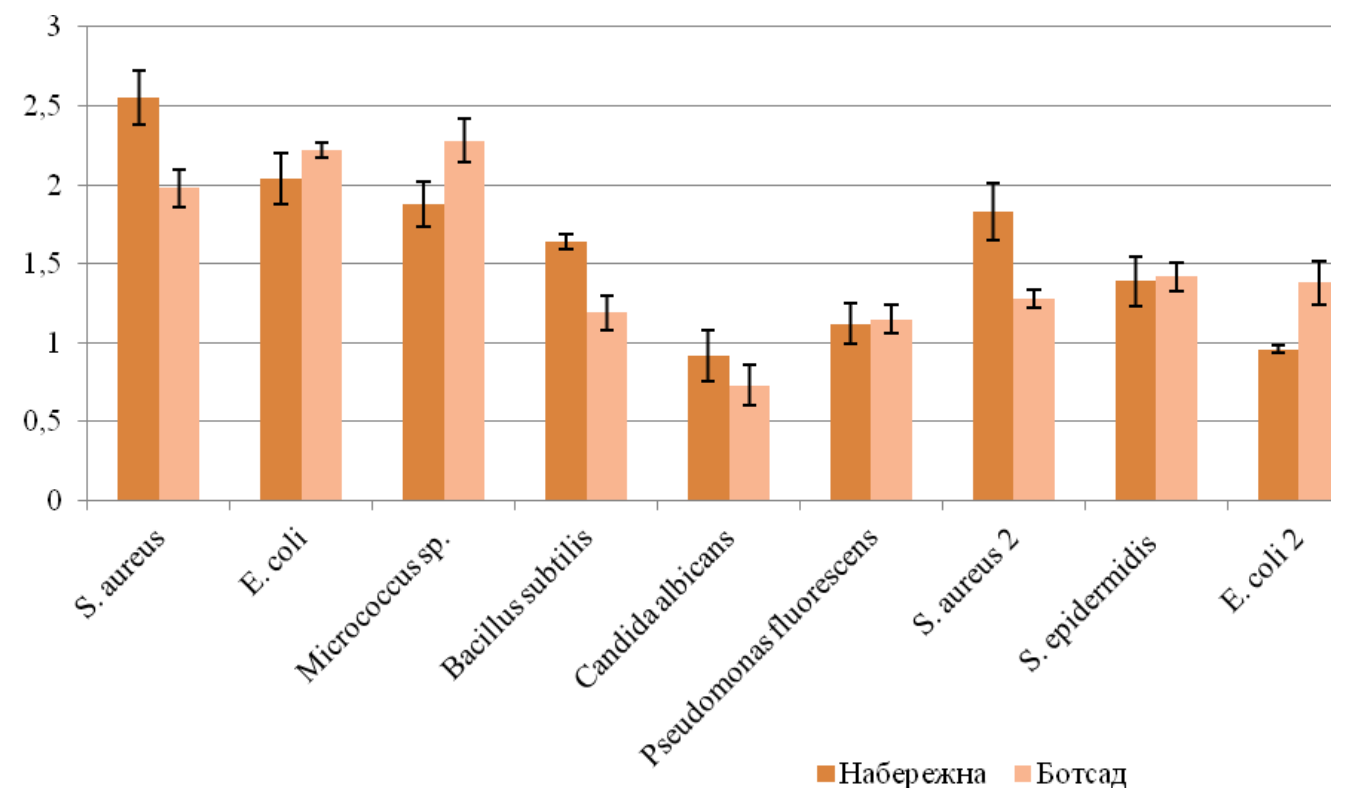

Рис. 1. Фітонцидна активність Thuja occidentalis у літній період, у.о.:

по осі абсцис - штами мікроорганізмів; по осі ординат - фітонцидна активність хвої

Аналіз динаміки досліджуваного показника хвої рослин із Ботанічного саду ДНУ свідчить про те, що найменша фітонцидна активність має місце взимку, навесні вона починає зростати, влітку є максимальною, а восени знову знижується. Можливо, це пов'язано 3 відсутністю в цей період року ростових процесів у пагонах Th. occidentalis. Так, пригнічувальна активність хвої на ріст тест-культур мікроорганізмів улітку була вищою, ніж узимку: у 2,46 разу у $S$. epidermidis, у 2,48 разу y B. subtilis, y 3,36 - y $S$. aureus, y 3,58 - y E. coli, y 4,43 у Ps. fluorescens та найсуттєвіше - у Micrococcus sp. у 5,85 разу. Лише один із досліджених тест-об'єктів C. albicans - показав більшу чутливість до фітонцидів Th. occidentalis не влітку, а восени й навесні.

Серед вивчених нами штамів мікроорганізмів в умовно чистій (контрольній) зоні за дії екстрактів хвої
Th. occidentalis найслабшого впливу на ріст зазнавали культури C. albicans. Фітонцидна активність на цей тестоб'єкт завжди була меншою за 1,0 у.о. Помірну пригнічувальну дію хвоя рослин, що зростають в умовах Ботанічного саду ДНУ, справляла на ріст таких мікроорганізмів, як $S$. aureus, $S$. epidermidis та B. subtilis. I лише на такі види, як Micrococcus sp., E. coli та Ps. fluorescens, фітонциди впливали суттєвіше, справляючи влітку високу бактерицидну дію: значення досліджуваного показника становили 2,22-2,48 у.о. залежно від виду мікроорганізмів (рис. 1-4).

В умовах інтенсивного автотранспортного навантаження вул. Січеславська Набережна динаміка фітонцидної активності хвої має подібну спрямованість. Однак кількість сполук, що виділяються рослинами, та їх активність суттєво різниться від контрольних величин.

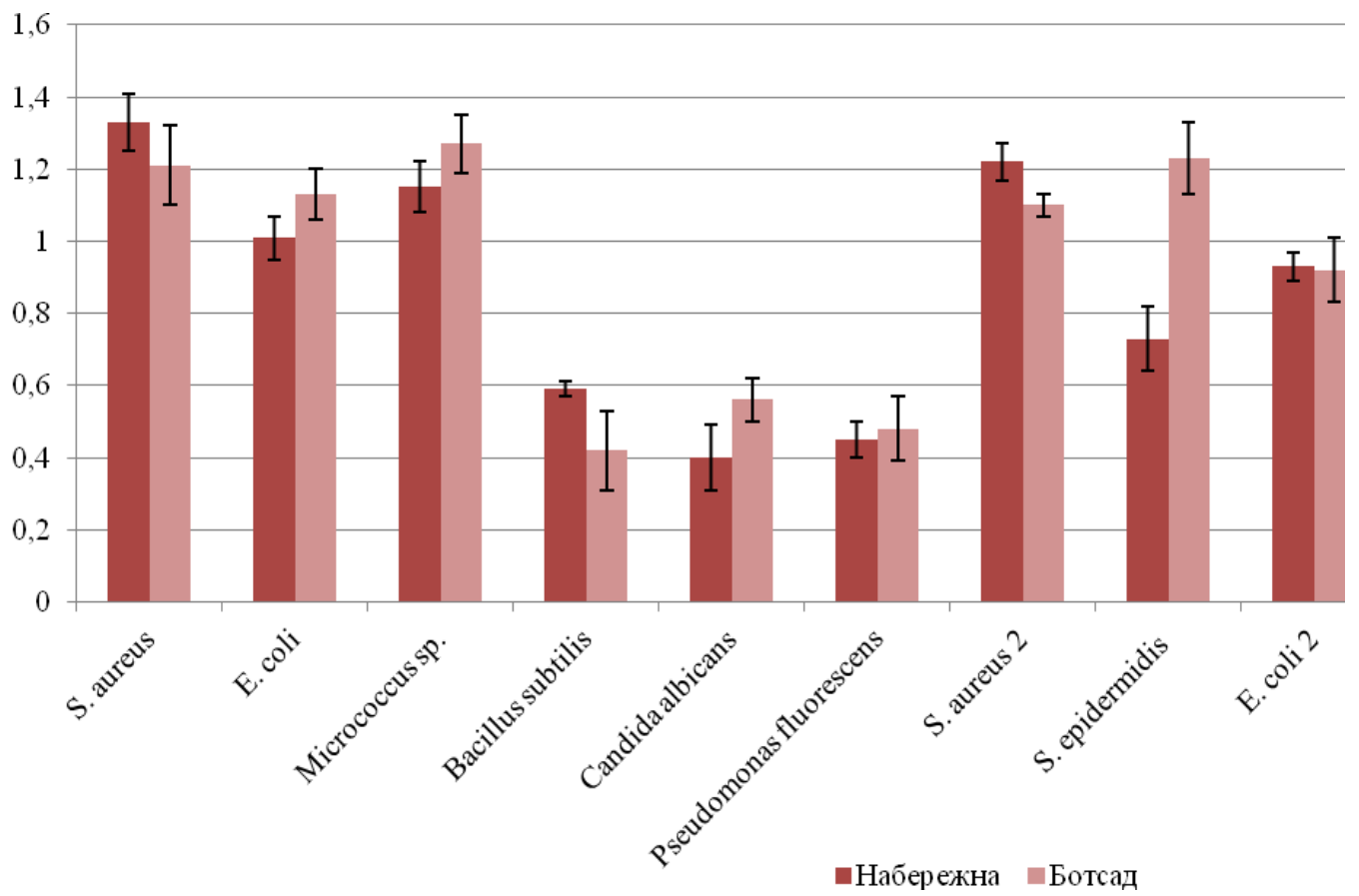

Рис. 2. Фітонцидна активність Thuja occidentalis в осінній період, у.о.: по осі абсцис - штами мікроорганізмів; по осі ординат - фітонцидна активність хвої 


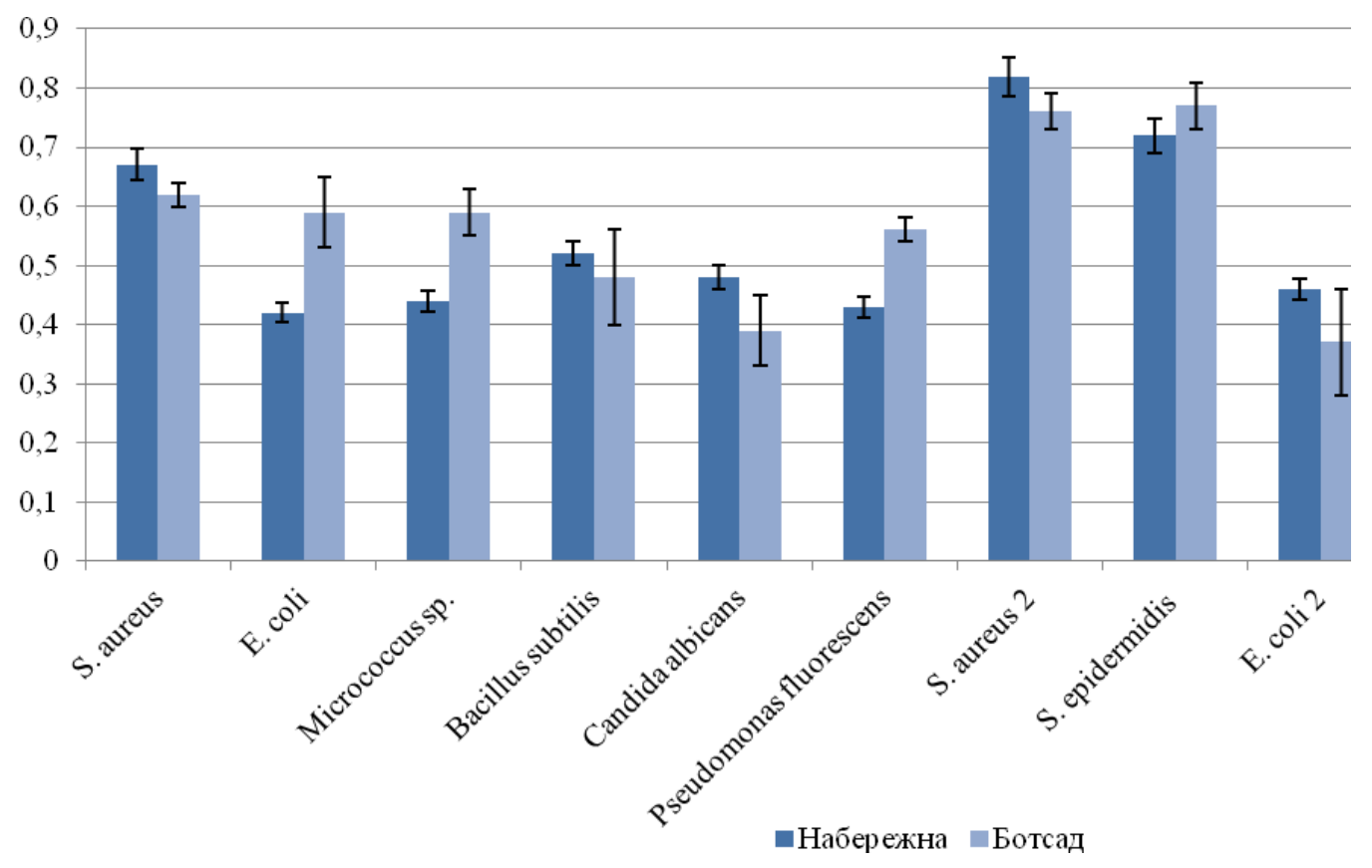

Рис. 3. Фітонцидна активність Thuja occidentalis у зимовий період, у.о.:

по осі абсцис - штами мікроорганізмів; по осі ординат - фітонцидна активність хвої

Як видно 3 рис. 1, влітку бактерицидна активність рослин Th. occidentalis має високий рівень за наведеною вище шкалою. Найбільшому впливу фітонцидів піддаються колонії S. aureus, для культур якого значення досліджуваного показника складає $2,55 \pm 0,17$ у.о. Майже не піддаються впливу фітонцидів колонії дріжджоподібних грибів C.albicans. Низькі показники пригнічення росту мікробних тест-культур властиві для грамнегативних Ps.fluorescens та грампозитивних паличок B. subtilis.

Для осіннього періоду характерне незначне зниження показників фітонцидної активності рослин через зниження температури довкілля та завершення росту пагонів (рис. 2). Бактерицидну активність у цей час можна охарактеризувати як низьку - показники не перевищують 1,4 у.о. В середньому активність летких фітонцидів у порівнянні 3 літнім періодом знизилася в 1,76 разу. Найвищий показник характерний для колонії $S$. aureus, на яку діяли екстракти хвої, зібраної з рослин, що зростають

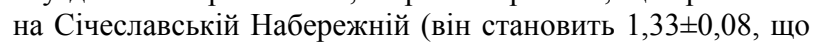
в 1,9 разу менше, ніж улітку). Так, як і влітку, восени найнижчою була пригнічувальна дія фітонцидів на ріст культур C. albicans, Ps.fluorescens та B. subtilis.

Узимку, порівняно 3 літнім та осіннім періодами, спостерігається найнижча фітонцидна активність досліджених хвойних рослин. Це ми можемо спостерігати на графіку активності туї західної щодо культур мікроорганізмів (рис. 3). Такий результат ми пов'язуємо 3 відсутністю ростових процесів у пагонах Th. occidentalis. Взимку значення показника, що характеризують пригнічення росту мікробних культур, низькі - у 2,8 разу нижчі, ніж відповідні показники літнього періоду, і в 1,6 разу - осіннього. Як видно із графіків, найбільш активний вплив фітонцидів взимку, так як і влітку і восени, має місце у колоніях S. aureus та Micrococcus sp., але сильніше пригнічувалися культури $S$. epidermidis.

Весняний період для хвойних характеризується тим, що рослини прокидаються після зимового сезону внаслідок підвищення температури навколишнього середовища i збільшення світлового дня. При цьому бактерицидна дія хвойних помітно зростає у порівнянні із зимовим періодом, що ми бачимо в отриманих показниках пригнічення росту бактеріальних культур (рис. 4). Фітонцидна активність екстрактів 3 пагонів Th. occidentalis, зібраних 30.03.2020 р., характеризується як помірна, хоча на деякі штами вона мала сильний вплив. Показники підвищуються до рівня помірної активності та коливаються від $0,43 \pm 0,17$ у.о. для C. albicans до $2,11 \pm 0,16$ у.о., що ми отримали для $S$. aureus.

Слід відзначити наявність літературних даних, що в цілому збігаються 3 результатами нашого експерименту. Фітонциди хвойних рослин впливають на ріст тест-культур мікроорганізмів по-різному. Так, за даними дослідників (Slepyih, 2004; Kima et al., 2013; Laireiter et al., 2013; Metsämuuronen, Siren, 2014; Vainio-Kailia et al., 2015), спостерігалася більша чутливість культур $S$. aureus до фітонцидів порівняно $з$ таким показником у E. coli. Ця закономірність властива для двох штамів стафілокока та кишкової палички, відібраних з різних біотопів.

Також, за даними інших авторів (Akimov, Ostapchuk, 1985), на кокоподібні мікроорганізми ефірні олії впливають більш активно, ніж на паличкоподібні бактерії. Це також можна спостерігати на представлених нами графіках фітонцидної активності Th. occidentalis у різних моніторингових точках.

Багато дослідників тестували ті чи інші види і генотипи (штами) Staphylococcus sp. та E. coli за їх стійкістю до екстрактів 3 фітомаси сосни звичайної та близьких до неї видів (Slepyih, 2004; Kima et al., 2013; Laireiter et al., 2013; Metsämuuronen, Siren, 2014; VainioKailia et al., 2015). У всіх цих роботах відзначена висока фітонцидна чутливість золотистого стафілокока $S$. aureus, у тому числі резистентних до певних антибіотиків штамів (Vainio-Kailia et al., 2015), а також менша чутливість E. coli.

За даними Metsämuuronen, Siren (2014), виявлено більшу чутливість до фітонцидів грампозитивних бактерій порівняно 3 грамнегативними. У роботах, в яких крім зазначених патогенів тестували також дріжджоподібні гриби Candida sp., зроблені висновки про високу фітонцидність сосни щодо бактерій, але дані щодо грибних патогенів неоднозначні (Janssen et al., 1986; Chao et al., 2000). Це може бути пов'язано з відмінностями як у методиках, так і в географічному походженні хвойних рослин.

Таким чином, фітонциди туї західної мають достатньо високу здатність пригнічувати ріст мікробних культур. Проте вона змінюється залежно від місця зростання рослин. 


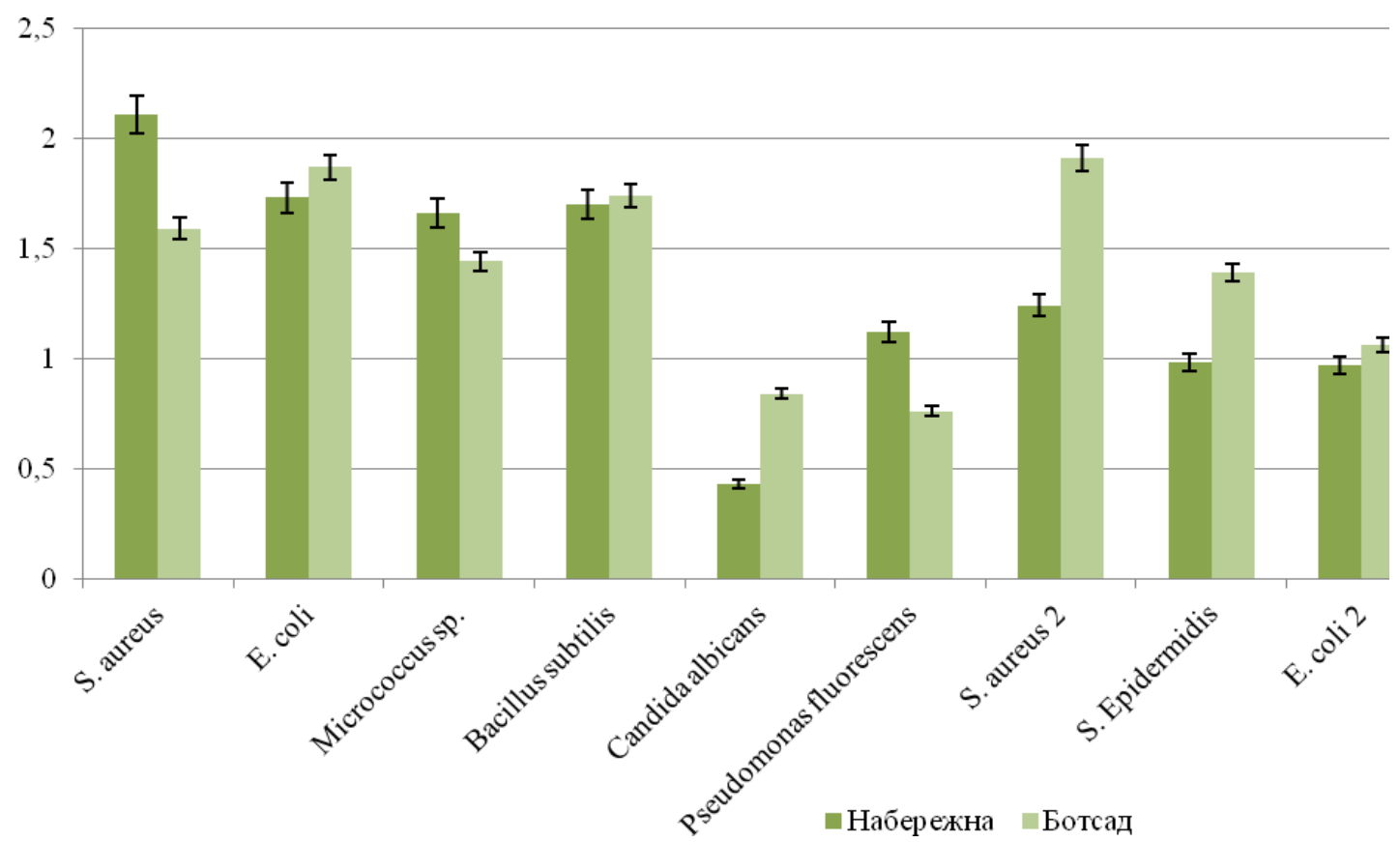

Рис. 4. Фітонцидна активність Thuja occidentalis у весняний період, у.о.: по осі абсцис - штами мікроорганізмів; по осі ординат - фітонцидна активність хвої

У моніторинговій точці 3 високим автотранспортним навантаженням бактерицидна активність рослин нижча, ніж в умовно чистій зоні. Це може бути пов'язано 3 погіршенням фізіологічного стану рослин, поганим станом грунту та його забрудненням.

\section{Висновки}

1. Дослідження динаміки фітонцидної активності хвої Th. occidentalis показало, що взимку пригнічувальна дія фітонцидів на ріст тест-культур мікроорганізмів найменша, навесні починає зростати, улітку $\epsilon$ максимальною, а восени знову знижується.

2. За техногенних умов зростання найбільшу антимікробну активність хвоя Th. occidentalis справляє на такі тест-об'єкти, як Staphylococcus aureus, Micrococcus sp. та Esherechia coli. У рослин, що зростають за хронічної дії автотранспортного забруднення, виявлено істотне зменшення фітонцидної активності хвої в культурах Candida albicans, меншою мірою - у Pseudomonas fluorescens та Bacillus subtilis.

\section{References}

Akimov, Yu. A., Ostapchuk, I. F. (1985). Dejstvie e`firny`kh masel na patogennuyu mikrofloru organov dy'khaniya [The effect of essential oils on the pathogenic microflora of the respiratory system]. IV Symposium on Oil Plants and Oils, Simferopol, 2, 42 (in Russian).

Bakulin, V. T., Chindyaeva, L. N., Tsybulya, N. V. (2010). Antymykrobnaia aktyvnost lystev topolei y yv (Salicaceae) v Sybyry [Antimicrobic activity of poplar and willow (Salicaceae) leaves in Siberia]. Problems of Regional Ecology, 6, 60-64 (in Russian).

Bessonova, V. P., Ponomaryova, O. A. (2017). Morfometrychni pokaznyky ta vmist plastydnykh pihmentiv khvoi Picea pungens zalezhno vid vidstani do avtoshliakhu [Morphometric characteristics and the content of plastid pigments of the needles of Picea pungens depending on the distance from the highways]. Biosystems Diversity, 25(2), 96-101.
Chao, S. C., Young, D. G., Oberg, C. J. (2000). Screening for inhibitory activity of essential oils on selected bacteria, fungi and viruses. J. Essent. Oil Res., 12, 639-649.

Dolzhenkova, O. V., Petrova, V. N. (2007). Vply`v avtomobil'nogo transportu na bezpeku zhy'ttyediyal'nosti meshkanciv m. Dnipropetrovs 'ka [Impact of road transport on the safety of residents of Dnipropetrovsk]. Bulletin of the Kharkiv National Highway University, 36, 56-60 (in Russian).

Ekolohichnyi pasport mista Dnipro (2016 r.) [Ecological passport of the Dnipro Sity (2016)] (in Ukrainian).

http://www.ieenas.org/p/tuia-zakhidna/

Iusypiva, T., Miasoid, G. (2016). The Impact of $\mathrm{SO}_{2}$ and $\mathrm{NO}_{2}$ Industrial Emissions on Anatomical Stem of Salix alba. International Letters of Natural Sciences, 51, 6-13.

Janssen, A. M., Chin, N. L. J., Scheffer, J. J. C., Baerheim Svendsen A. (1986). Screening for antimicrobial ctivity of some essential oils by the agar overlay technique. Statistics and correlations // Pharmaceutisch Weekblad, 8, 6, 289-292.

Kima, H., Leeb, B., Yunc, K. W. (2013). Comparison of chemical composition and antimicrobial activity of essential oils from three Pinus species. Industrial Crops and Products, 44, 323-329.

Laireiter, C. M., Schnabel, T., Köck, A., Stalzer, P., Petutschnigg, A., Oostingh, G. J., Hell, M. (2013). Active anti-microbal effects of larch and pine wood on bacterial strains. BioResources, 9 (1), 273-281.

Pasichnyy, H. V., Serdyuk, V. M., (2002). Dynamika vazhkykh metaliv $\mathrm{v}$ gruntovomu pokryvi u zvyazku $\mathrm{z}$ tekhnohennym zabrudnennyam otochuyuchoho seredovyshcha (na prykladi m. Dnipropetrovs'ka) [Dynamics of Heavy Metals in the Soils is Dealt with the Technogenic Pollution of Environment (for Example of Dnepropetrovsk City)]. Ecology \& Natural Resource Management, 4, 111-117 (in Ukrainian).

Potichuk, O. V., Pilipaka, O. V. (2013). Guidelines for the implementation of the calculation and graphic work on the topic "Traffic characteristics and parameters of traffic flows" in the discipline "Monitoring traffic flows". NUPGP, Rivne. (in Ukrainian). 
Sari Metsamuuronen, Heli Siren. Bioactive phenolic compounds, metabolism and properties: a review on valuable chemical compounds in Scots pine and Norway spruce. Phytochem Rev, 18, 623-664.

Slepyih, V. V. (2004). Prirodny`e i antropogenny`e faktory` i fitonczidnaya aktivnost' drevesny'kh porod. [Natural and anthropogenic factors and phytoncide activity of woody plants]. Forestry gardening, 6, 17-19 (in Russian).

Tokin, B. P. (1980). Czelebny`e yady' rastenij. Povest'o fitonczidakh. [Healing poisons of plants. The tale of phytoncides]. Izd-vo Leningr. universiteta, Leningrad (in Russian).

Tsybulya, N. V. (2001). Metodika opredeleniya fitonczidnoj aktivnosti intaktny'kh rastenij [Methods of phytoncideactivity estimation in intact plants]. Plant Resources, 2, 106-115 (in Russian).

Tsytsyura, N. I., Holovatuk, L. M. (2016). Likuvalni vlastyvosti predstavnykiv rodyny Cupressaceae F. Neger // Investigations of medical plants - theoretical and practical aspects : Proceedings of $2^{\text {th }}$ International scientific and practical Internet-Conference. Kharkiv, 260-261 (in Ukrainian).

Vainio-Kailia, T., Kyyhkynen, A., Rautkari, L., Siitonen, A. (2015). Antibacterial effects of extracts of Pinus sylvestris and Picea abies against Staphylococcus aureus,
Enterococcus faecalis, Escherichia coli, and Streptococcus pneumoniae. BioResources, 10 (4), 7763-7771.

Volodarets, S., Gluchov, A. \& Zaitseva, I. (2018). Phytoncide activity of woody plants under the conditions of steppe zone. Ekologia (Bratislava), 37(3), 219-229.

Yusypiva, T. I. (2018). Stan sosnovykh nasadzhen rekreatsiinoi zony poblyzu Prydniprovskoi TES ta yikh rol v ozdorovlenni miskoho seredovyshcha [The state of pine green planting in the recreational area near the Prydniprovsk TPP and their role in transforming the urban environment into the health-friendly one]. Biological, medical and scientific-pedagogical aspects of human health: Proceedings of International scientific and practical Internet-Conference. Poltava, Ukraine, 239 (in Ukrainian).

Yusypiva, T. I., Slobodyanyuk, O. O. (2019). Bakterytsydna aktyvnist khvoinykh introdutsentiv v umovakh m. Dnipro [Bactericidial activity of coniferous introduced species in the conditions of Dnipro]. Plants and Urbanization: Proceedings of VII International scientific and practical conference. Dnipro, Ukraine, 110-111 (in Ukrainian).

Zaitseva, I. O., Opanasenko, V. F. (2008). Putivny`k po botanichnomu sadu DNU. [Guide to the Botanical Garden of DNU]. DNU Press, Dnipro. (in Ukrainian). 